\title{
GODS AND DEMONS, BEAUTIES AND ZOMBIES: THROUGH THE PAGES OF CHINESE EDUCATIONAL MAGAZINE "CULTURAL HERITAGE OF CHINA"
}

\section{Elina A. Sarakaeva (a)}

(a) Hainan College of Economics and Business. Haikou, China. Email: 2689655 292[at]qq.com

\begin{abstract}
This work reviews the Chinese cultural and mass-educational magazine "Cultural Heritage of China" going through several issues of the magazine - those of 2016, 2017 and 2020 years. The brief history of how the magazine was established and structured is given in the first paragraphs. Following are the reviews of the magazine's issues about the vestimental culture of China, the sensitive question of borrowing elements of Chinese culture into the Japanese oral tradition, the history of state examinations. In the last part of the review I analyze the contents of the special issue on Chinese spirits and demons.
\end{abstract}

Keywords

magazine; China; Chinese; culture; "Cultural Heritage of China"; magazine issue 


\title{
БОГИ И ДЕМОНЫ, ДЕВЫ И ЗОМБИ: ПО СТРАНИЦАМ КИТАЙСКОГО ПРОСВЕТИТЕЛЬСКОГО ЖУРНАЛА «КУЛЬТУРНОЕ НАСЛЕДИЕ КИТАЯ»
}

\section{Саракаева Элина Алиевна (а)}

(a) Хайнаньский институт экономики и бизнеса. Хайкоу, Китай. Email: 2689655 292[at]qq.com

\begin{abstract}
Аннотация
В статье приводится обзор китайского культурного и массово-просветительского журнала «Культурное наследие Китая», рассмотрены несколько выпусков журнала - за 2016, 2017 и 2020 годы. В первых абзацах представлена краткая история создания журнала и описана его структура. Далее приводится ревью номеров журнала посвященных вопросам китайской вестиментарной культуры, вопросам заимствования элементов китайской культуры в японскую устную традицию, истории государственных экзаменов, анализируются религиоведческие статьи о духах и демонах Китая.
\end{abstract}

Ключевые слова

журнал; Китай; китайский; культура; «Культурное наследие Китая»; выпуск журнала

Это произведение доступно по лицензии Creative Commons «Attribution» («Атрибуция») 4.0 Всемирная 
The Chinese cultural and mass-educational magazine "Cultural Heritage of China" was first published in December 2004, sponsored by the China Bookstore, co-organized by the State Administration of Cultural Heritage of China, the Ministry of Construction of the People's Republic of China and the Chinese National Commission for UNESCO. It publishes monthly issues on Chinese traditional culture. History, literature, fine arts, architecture, folklore are within the sphere of its publications. The magazine claims to concern itself "with the oral and intangible heritage of humanity", but since it was first published in 2004 up to 2020 it has found no space for any other humanity other than the Chinese nation, so it would be more correct to disregard the world-wide claims and accept the magazine as introducing to the general Chinese-language reader some facts about Chinese culture.

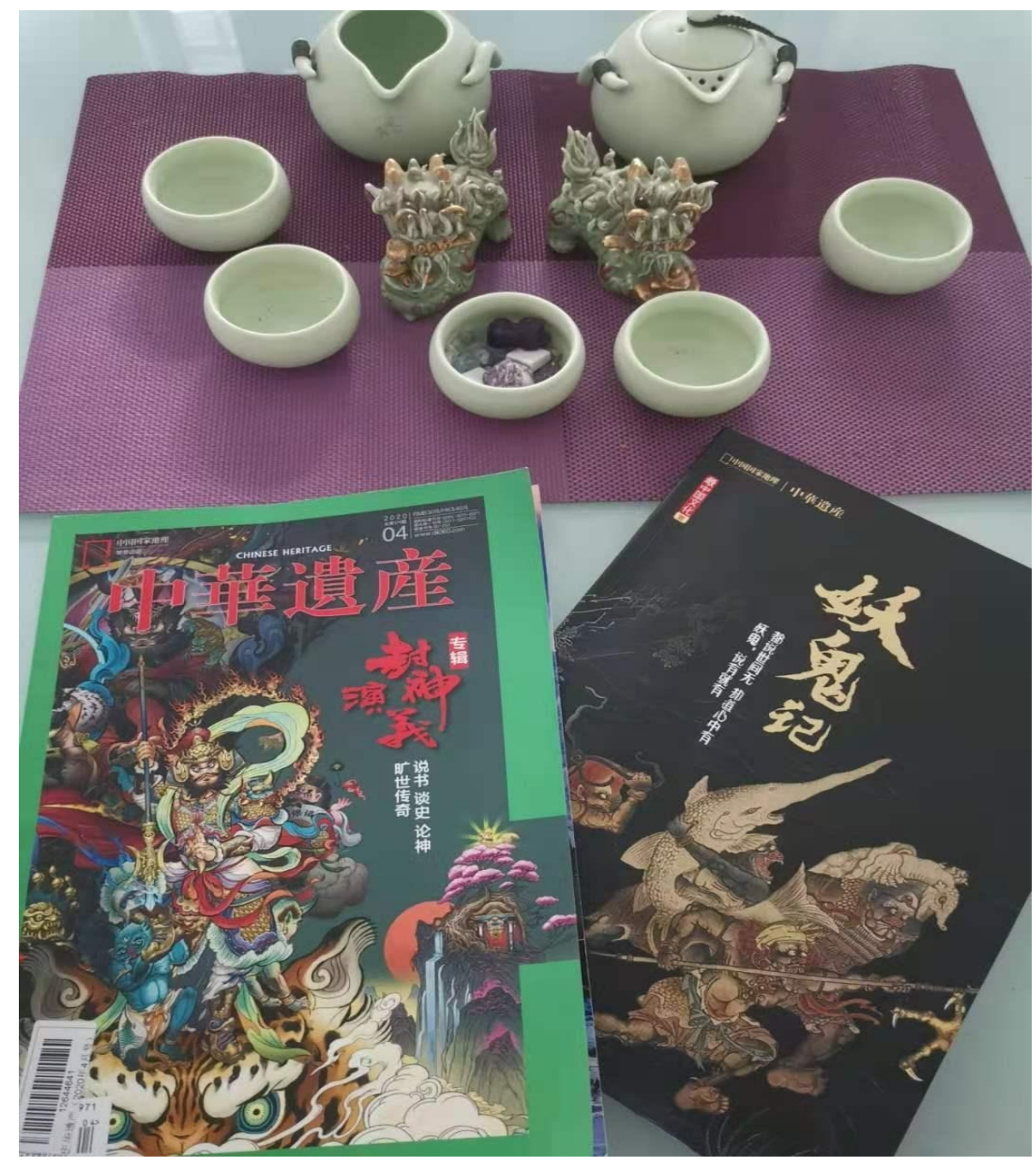

Picture 1. "Cultural Heritage of China". Issues of 2020. Cover images 
Among its competitors "Cultural Heritage of China" is without any exaggeration the best of its kind. It is the first comprehensive systematic magazine in China, published by China National Geographic and Chinese Cultural Heritage Foundation and supported by World Natural and Cultural Heritage Foundation, China Folklore Photography Association and the Beijing Representative Office of UNESCO. Recently the magazine has been transformed from a collection of fragmented articles to a manypaged journal with beautiful coloured illustrations, perfect polygraph work and interesting contents.

The renewed magazine has organized influential contests such as "The Most Chinese Characters" and "The 100 Most Significant Archaeological Discoveries of Chinese Civilization".

In February 2008, the magazine formally cooperated with National Geographic China and launched its first renewed issue (Issue 28-29, Feb$03,2008)$ in the same month. The new slogan of the magazine is "Let the past illuminate the future, let history influence the present - we are here to share history and taste it together".

The magazine aims at:

- giving a historical perspective on China and the world;

- sharing with their readers the beauty of the humanities and exploring Chinese cultural treasures;

- providing an interesting reading for those who love history.

They introduce themselves as "an authoritative magazine that will never go out of date" and claim that "anything of value that happened yesterday is our content, any history that interests you is the subject of our attention". They promise to enlighten and to uncover secrets. The high mission of "Cultural Heritage" is "to analyze the legacy of civilization and highlight the humanistic concern". Again, the civilization mentioned here is no other than the Chinese civilization, which in itself is quite enough for any periodical.

"Cultural Heritage" also serves as an important channel of communication between China's heritage sites, prospective World Heritage sites and UNESCO.

The magazines earned all sorts of praises and general acclaim all over China, it enjoys only positive reviews from critics and readers. The critic, who writes for "Planet Geographic Quest" under the pseudonym The King of National Geography appraised the magazine with the following remark: "The value of the magazine's content lies firstly in the fact that their exclusive and deep content can be commercialized, they can cooperate with 
other periodicals.....It is priceless, because it reveals the spiritual force that contributed to our success over the past 5,000 years, and is the reason why we are Chinese" (King of National Geography, 2019).

The magazine is by no means an academic periodical, the articles published there are no scholastic papers and don't claim to say a new word in history or culture studies. The magazine rather explains to the reader facts and realities of Chinese tangible and intangible objects of culture, provides interpretation and detail descriptions to the things the readers already know, at least at the surface level. Yet for the representation sake some articles, especially at the beginning of the magazine's post-reform life, were written by political figures, renowned scholars and experts. Thus, Zhang Xinsheng, Chairman of the 28th session of the UNESCO World Heritage Committee, wrote the launch address; Mr. Banderin, Director of the UNESCO World Heritage Centre, wrote a congratulatory message for the first issue; Qiu Baoxing, Vice-Minister of Construction, Mr. Guo, Inspector and Director of the World Heritage Department of the State Administration of Cultural Heritage, Feng Jicai, Vice-Chairman of the China Federation of Literary and Art Circles, and Yu Qiuyu, a famous scholar, all published relevant articles to ensure the authority of the magazine's content.

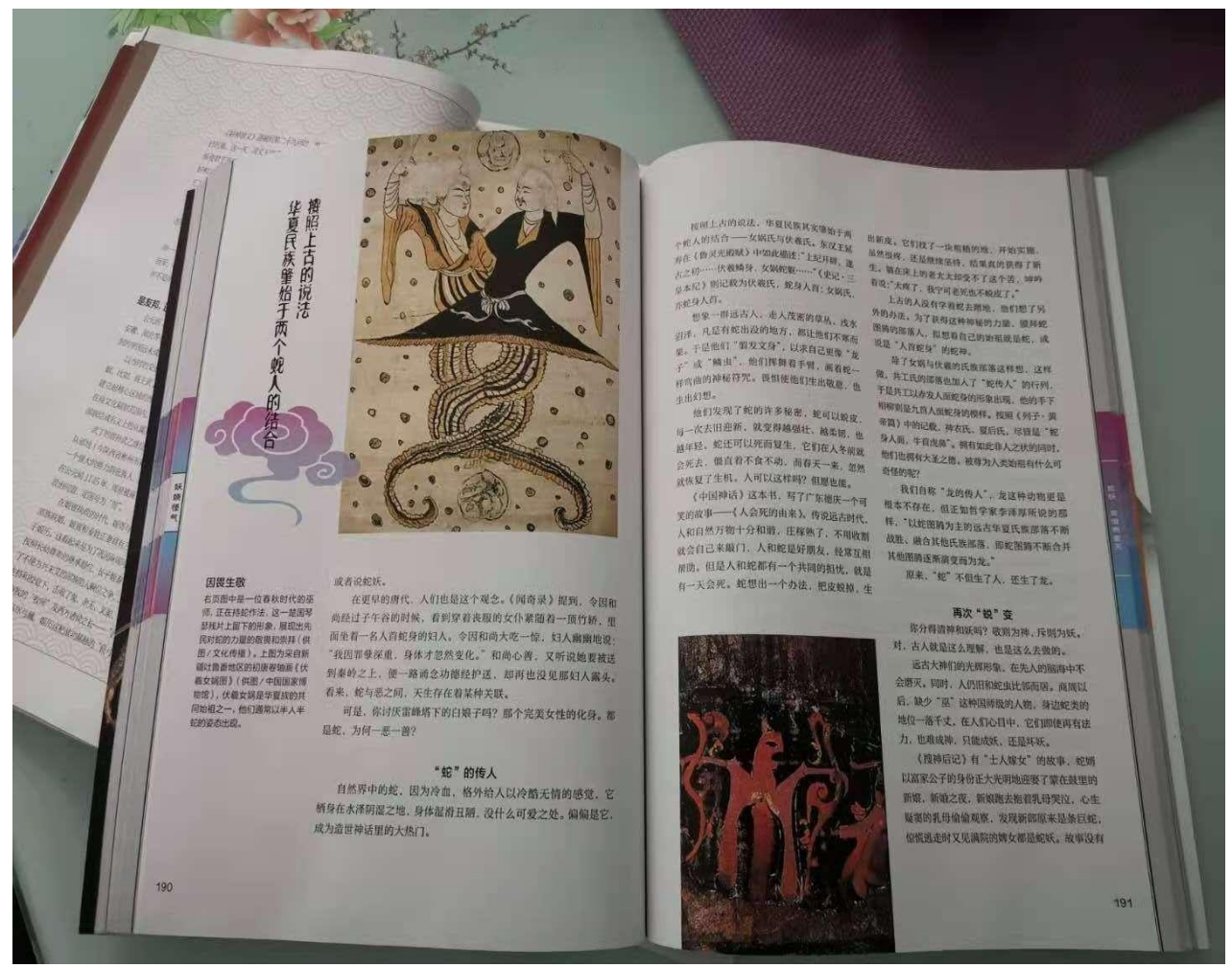

Picture 2. "Cultural Heritage of China". Special issue of 2020. An article about origin of snake deities 
To give the reader general impression of the style the magazine employs and its typical content I give hereby a brief review of several issues published in the period 2015-2020 years.

Issue No 6 of 2017 is entitled "Imperial Examinations" and all the articles there deal with this or that aspect of the famous exams, the neverending source of Chinese bureaucracy. The leading article of the issue, "Examinations in the city of Chang'an" describes the preparation schools that helped the seekers to prepare for the exams.

The article tells that there were two main sources of candidates for the imperial examination in the Tang dynasty. One such source was the "apprentices" from government-run schools, and the other was the "country tributes" recommended by local governments. The State Academy that was responsible for this preparation was divided into six brunches: Imperial College, Court School, School of Six brunches, School of Law, School of Calligraphy and School of Arithmetic. Of these the last three were specialized, but were considered to be relatively low-level and not politically influential. The difference between the more prestigious schools was not in the subjects they taught but in the parents of the students. The parents of students in the Imperial College were the most powerful officials, often of no less than the third rank in the civil and military hierarchy. The majority of students at the Imperial College were relatives of the court eunuchs (about 62\%) (Liu Bo, 2017, p. 12). Thus, though the imperial examination system officially was open to all the strata of the society, only the children of the powerful and rich can benefit from it, which turned it to no more than just a selection test within the original elite class, while the general public had almost no access to the examinations and the official positions that they served a bridge to.

The imperial examination system, according to one more article, had two main functions: to select officials for the ruling class and to provide an occupation for the members of elite. The author believes that from the point of view of selecting administrative talents it has never been a very good system. In the Han dynasty, at the dawn of Chinese Empire, local officials recommended talents to the central government on the following grounds: the candidates should be versed in the law, be of morally impeccable behaviour and be good at dealing with difficult problems. So a person selected according to these criteria would have at least some experience of dealing with practical problems and would be far more experienced than a poet or a composer. Later these criteria were dropped or turned into mere formality, the candidates were selected based on the results of multilevel scholastic examination that proved their mastering of Confucian books and good memory. The public availability of the official 
posts through exams also degraded to a formality. An official of the Tang period Li Deyu stated openly that: "For a prominent official in the imperial court, it is necessary to be parented by a public official. Since the children of ministers are exposed to the rules and routines of the governmental machinery from childhood, they are naturally more familiar with them. But even the most talented scholar from a poor background has to face a difficult period of transition after joining the court" (Cultural Heritage of China 2017, 67). In some cases, the examiners did not even look at the examination papers while selecting the winners.

It's curious that in attempt to defend the examination system many contemporary writers would say that the "poor and lonely" sometimes had an advantage over the "children from the rich families". However, modern scholars after a quantitative analysis found out that the term "poor and lonely" refers to "all those who entered the imperial service other than the children of officials", which in fact means the children of lower-middle-class bureaucratic families and the old scholarly families.

The author concludes that the Tang dynasty nevertheless was not a society in which the ordinary people had no hope of upward mobility (after having carefully proven to us otherwise). As an argument he says that the largest proportion of Tang officials were so-called "in-ranking officials", i.e. those who were originally junior civil servants but because of their good work performance gained a rank and became lower-level officials. However, there was basically no hope of further promotion for them. So much for the upward mobility of the Tang.

There are also some legends and fiction stories in the issue related to examinations. One story in particular, written by medieval writer Xue Yongqiang and retold in the journal is worth mentioning, for though it is supposed to be a praise of a talented scholar, it in fact unintentionally demonstrates the level of objectivity of imperial exams. There was during the reign of Tang dynasty a young man called Wang Wei whose talents won the favors of the Emperor's brother. The prince wanted to promote his favourite to some high official position, but for that Wang Wei had to pass the examinations together with other candidates. In order to be admitted to the exams this scholar Wang needed a letter of recommendation from the local authorities. He couldn't obtain it, because another member of the royalty, the ninth daughter of the Emperor, had her own favourite, also a renowned scholar, and made it known to the officials that she expected the recommendation letter for her own protege. The prince then invited the princess to a banquet where she saw Wang Wei and was so impressed by his beauty, his music and his poetry that she changed her mind in favour of Wang and demanded the recommendation letter for 
him instead of her former favourite. Thus the members of the emperor's family, who were not supposed to have any say in the results of the examination, in fact decided among themselves who will win and who will lose.

Yet another article compares the present day Chinese gaokao system - the exams taken by high school students seeking admission to universities - with imperial system of Confucian scholastic exams taken by candidates for official posts. The history of the gaokao can be indeed traced back to the imperial examination, with its practice of sealing examination questions and solemnly breaking the seals in the examination rooms, strict secrecy of the contents and general exclusive atmosphere. The difference between two examination systems the author of the article sees in the fact that the imperial court produced but a few successful candidates (jinshi) who were admitted to the ranks of bureaucracy. The average number of candidates admitted each year in the Tang dynasty was no more than twenty, whereas nowadays those who are able to pass such exams are many. The article clarifies that "In today's college entrance examinations, the top provincial candidates would be called 'scholar candidates', and with the division into arts and science subjects, this means that more than 60 scholar candidates would be produced each year, more than three times the number of jinshi in the Tang dynasty. Such a limited number of candidates was simply not enough" (Liu Bo, 2017, p. 11).

The articles of the issue are illustrated with colourful reprints from medieval books. There are also photographs of historical relics - the examination hall, the interior design of royal academy etc. Some modern artists contributed their paintings too.

To give the reader an idea of the style of writing the magazine often employs I provide a word-per-word translation of two extracts from two 2017 issues, that speak about dresses and vestments throughout the Chinese history:

"The body of a petite Chu woman was delicately and gracefully shaped by the 'deep garment', while the plump body of a Tang dynasty lady was even more feminine when wrapped in the loose dress. The thousand-fold pleated 'horse-faced skirt' was made to follow the steps of females of the Ming and Qing dynasties, revealing the glory of the delicate embroidery between the pleats. The 'qipao dress'.... proclaimed the self-reliance and independence of women in the new era...... These are images that are unique to China and we should not forget them" (Who is there half-covering...2017, 41); 
"Nowadays, beauty is in the face, but in the olden days, when beautiful women approached, even the tinkling sound of their footsteps could signal of infinite musical beauty. This, of course, is because they had an indispensable decorative magical thing - the ring pendant. In fact, the ring pendant was a product of the hierarchical society of the Western Zhou Dynasty, with different jade pendants symbolizing different classes and strictly maintaining social order. Therefore, wearing jade pendants was not simply for the purpose of listening to their sounds, but more for the purpose of ritual, that is, "to listen to oneself and the chime, so that the sound of jade is in tune with one's walk" (Jingling rings on the skirt, 2017, p. 20).

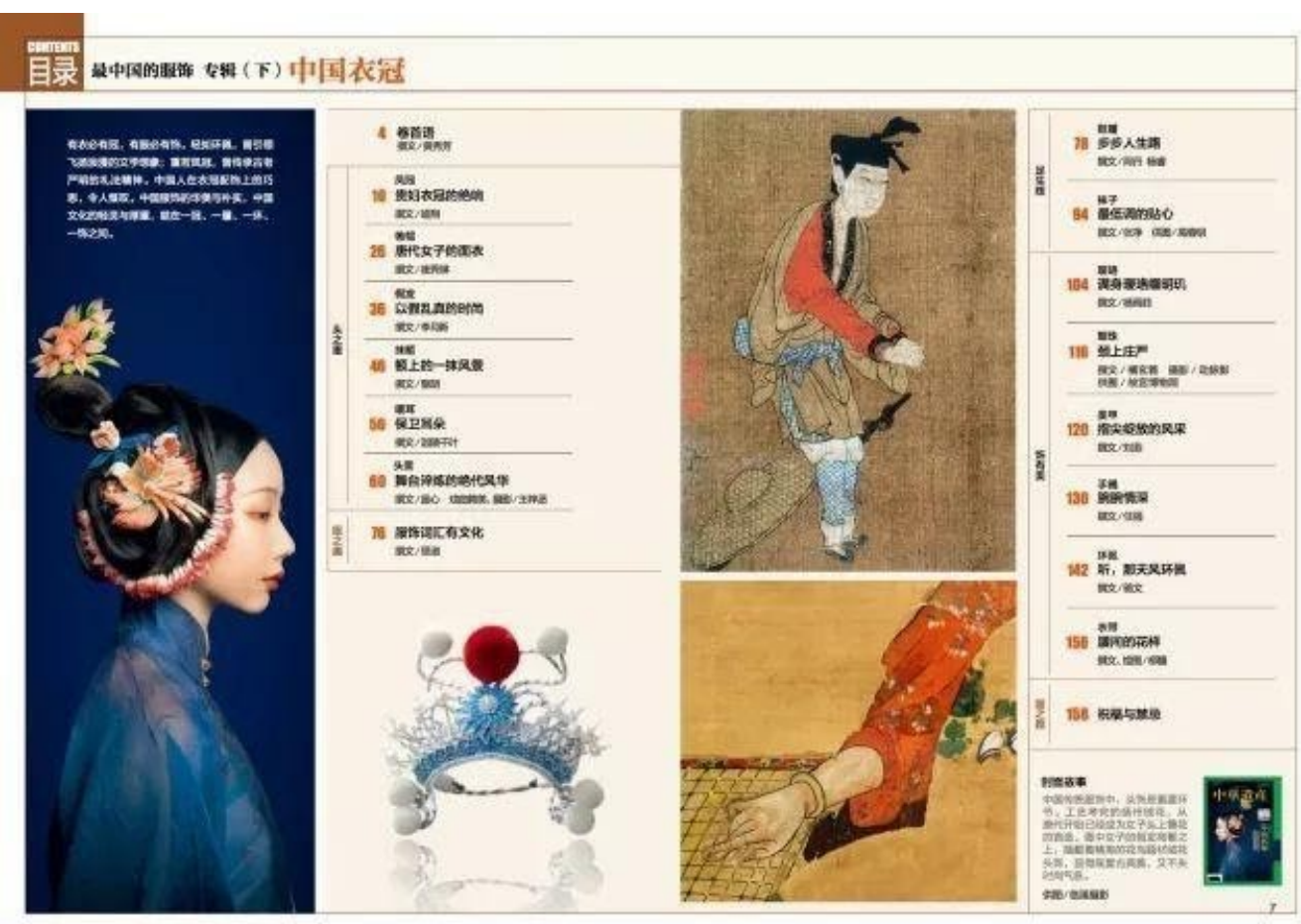

Picture 3. "Cultural Heritage of China". The issue of 2017 No 11. The index page

One more interesting issue of the magazine attracts interest due to the fact that its whole contents express the popular idea, that everything worth noticing in Eastern Asian countries was borrowed from China. This outspoken blatant China-centrism can be found in many books, public lectures read by Chinese professors, academic articles, TV-documentaries and textbooks. From the screens of television and in school and University classrooms the Chinese persuade each other not only that their culture is the best in the world but also that any other masterpiece of culture was invented by the Chinese and borrowed by foreigners, especially by 
their neighbouring countries who at this or that period of history experienced Chinese influence. The Japanese kimono was not created by the Japanese - it was borrowed from China. The Korean female vestment (as in fact the Korean everything) was borrowed from China. Even Russian dumplings were borrowed from China. Why? Well, because Russians eat dumplings, the Chinese eat dumplings too, which in itself is a proof. The idea that something in any other country can vaguely resemble something Chinese without being actually borrowed never occurs and is never discussed. It is enough to find something with resembling features in both cultures to make the Chinese claim it is invented by them and borrowed by others.

The No 8 issue of 2016 follows this line. It is entitled "Cultural Heritage of China. Ghosts of the Night: Monsters exported from China" and describes various ghosts and demons of Japan - only to claim that their images were borrowed from the Chinese culture. The article starts by describing The Night Parade of Demons as a cultural phenomenon. The Night Parade of Hundred Demons is a Japanese folklore legend that refers to a parade of monsters and goblins that takes place on a summer night. The legend developed from the oral tradition, and was first described in the records of the Heian Period (794-1192 AD): the sources depict ancient Kyoto as a world infested by spirits and ghosts. The demons and monsters did not just linger in the deep woods or in the underworld - they sometimes lived under the same roof and in the same city as humans. In summer, as soon as darkness fell, the demons would parade in groups along Kyoto's avenues. If any human happened to catch a glimpse of this parade, they would be cursed and die a sorrowful death.

The legend was illustrated by many Japanese artists, including the famous Toriyama Ishiyan, who all his life painted mostly goblins and monsters, the imperial painter Mitsuonobu Tosa from the Muromachi period, Yoshiyuki Tsukioka, an ukiyo-e painter from the Edo period etc. The works of Japanese authors are renowned for intricate details and preciseness: each monster has its own peculiar features but through their frightful deformity one can recognize the original things from which they transformed - a hair comb, a lute, an umbrella. That's because many of such demons were not some evil spirits from outside the human world they were usual household utensils, old artifacts forgotten and neglected by the owners turned into monsters out of spite or just old age.

The modern entertainment world also pays tribute to this legend. The Night Parade of Demons has been adapted into numerous anime and film productions that have swept the world. One can find it in modern horror novels, manga, animated series and films. 
Then the author claims that those colorful images of ghosts and demons are in fact Chinese by origin: "However, not many of the hundreds of ghosts parading around are native to Japan, and most of them came from China" (Xiao Xi 2016,6). The author would repeat this idea again and again, without proof or reason other that in the literary works of some Chinese authors - like early Jin dynasty author Gan Bao and late medieval Pu Songlin - one can find descriptions of similar demons.

The other argument to the claim that Japanese demons were borrowed from China is given in the summary: "Chinese monsters were "exported" to Japan in large numbers during the Tang Dynasty in China, the Japanese Nara and Heian periods. At that time, a large number of Japanese envoys came across the sea with an open mind to study Chinese culture. Japan imitated the laws, political system and capital construction of the Tang dynasty, and even demons and monsters were copied from China. Chinese demons and monsters have gradually penetrated deeply into the Japanese folklore with the arrival of classical literature It can be said that China played a vital role in the real formation of Japanese demon culture" (Xiao Xi 2016,11). That's it. No details, no quotations of any research, no citations or proofs.

I am not trying to dispute here the idea that Japanese demon mythology borrowed a lot from China - it might very well have done so or it might not. It is the level of argumentation that "Cultural Heritage of China" generally provides for their claims that I point out here.

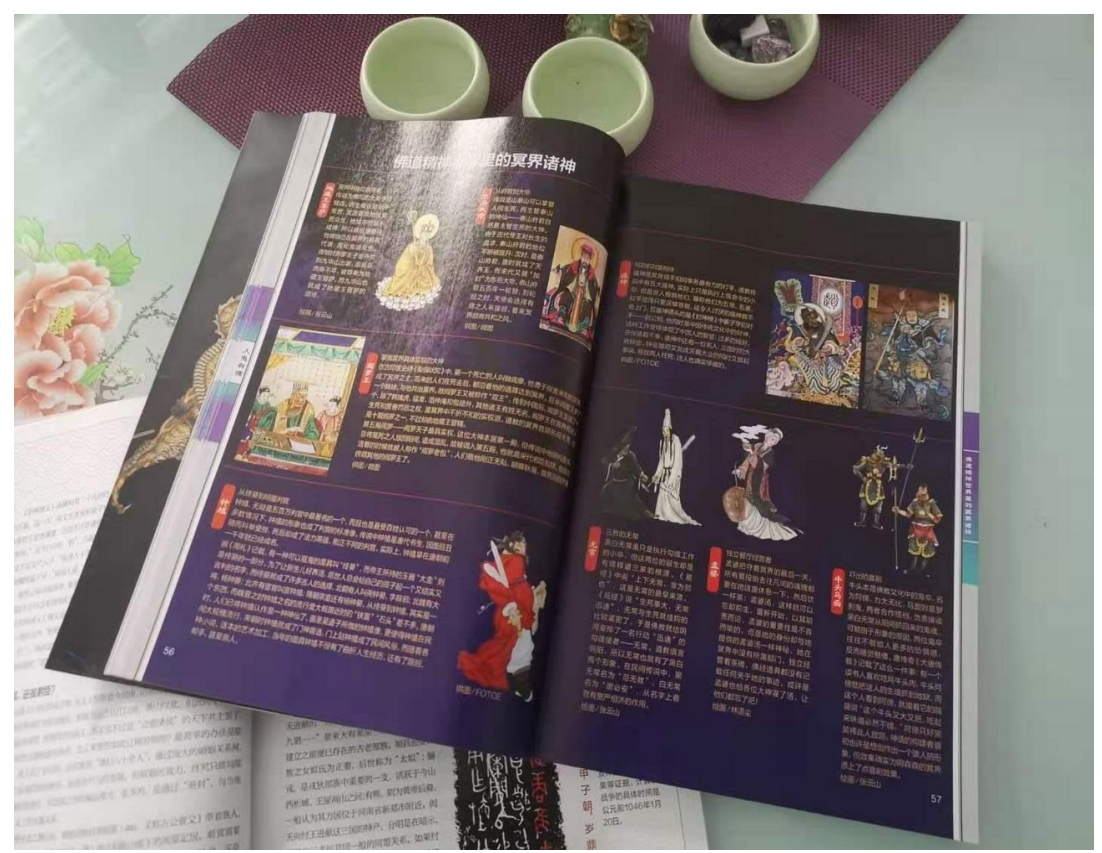

Picture 4. "Cultural Heritage of China". The special issue of 2020. The article about Buddhist and Taoist deities 
The issue of the magazine that I really enjoyed reading was the latest special issue about the Chinese demons called "The Book of Ghosts and Demons". Published in 2020, it has no number, for it is a special additional issue, a big 295-paged book (twice as big as a usual issue), magnificently illustrated and with excellent polygraph work. The issue is a sort of allround encyclopedia of Chinese demons and evil spirits: their sorts and classes, their origins and cults, their history and related modern practices and traditions, ghost-worshiping carnivals and specifics of Chinese zombies. The illustrations are both modern photographs of masks, demon-related paraphernalia, exorcisms etc. as well as reproductions of medieval engravings and other works of art depicting demons.

It would take too much space and time to review here all the rich and interesting contents of the issue, so I chose a few.

One of the most curious elements of the issue are graphic schemes of evil spirits explaining various elements of their images and their symbolism. The reader can learn what exactly is symbolized by each head of a three headed-deity, by each arm of a six-armed demon. This kind of information is quite unique and hard to find for either a Chinese or a foreign reader. Thus, we can learn that there are 8 types of Chinese zombies, including the hairy zombie whose body is covered with fur, the white zombie whose body is covered with white fur, the purple zombie with purple fur, the green zombie with white hair and green fir, the flying zombie who can fly, the swimming zombie who can swim, the immobile zombie - an indestructible corpse that cannot move, and the part-zombie whose certain body parts are indestructible while the others can decay. To fight against these creatures one uses dog's blood, chicken's blood, Taoist sword made of peach tree, papers with magic spells written in red ink etc. Evil Taoists use zombies to wrack chaos, controlling them with magic books and magic bells the sound of which makes the living corpses move in a certain direction. A terrifying zombie bride is a heroine of many modern Chinese horror movies - this image is inherited from a long tradition of real ghost weddings. According to archaic beliefs, unmarried females couldn't enter their ancestors' post-mortem realms, so the parents of a deceased girl organized a ghost wedding to marry her spirit to some male, dead or alive. This was more often done with a picture or a photo of the deceased, though actual dead bodies still sometimes participated in the ceremony (and still do) (Sheng Wenchang 2020, 95-96). An unmarried young man could enter the otherworldly realm, but he would still be unmarried there and also needed a bride to be wed to. These traditions are believed to be one of real-life sources of the zombie legend. 
One of the best, to my mind, articles of this issue explores the selfidentification of believers with demonic beings during the rituals of exorcism. The cults of evil gods in South China was described in the work of a few researchers (me including) -it is an interesting phenomenon worth of attention of anthropologists and culture researchers. Behind the respectable facade of many Chinese deities lies their obviously demonic origin. For example, the wangye (princely) spirits, who cure diseases, in fact send out these diseases themselves. Their modern cult in Taiwan reflects their dual nature; believers worship and expel them at the same time. Even when people make sacrifices, they put the images of these deities in a boat that goes out to sea or is burned (Katz 1987, pp. 197-215). Similarly, in South China the Gods of the Five Ways to Wealth are worshiped (ulu tsaishen) - their cult first appeared in Jiangnan in the 17th century. These five deities descended from mountain spirits called Shanxiao, one-legged villains known for throwing stones at lonely travelers and throwing them off the path. Just like the wangye spirits, these devilish deities are simultaneously worshiped - sometimes through female shamans who claim to have sexual intercourse with them - and exorcised (Glahn 2004).

A very worthy contribute to the exploration of such cults is offered by the journalists of the special issue of 2020. The authors Zhuang Wen, Guo Jing and Zhang Jing describe self-identification of believers with their revered deities in the worship rites of the Nuo exorcisms in the southern provinces of China. The rites include offering sacrifices, burning incense and sacrificial candles, but the most important part of them is the dance of masks.

Brightly coloured ritual masks are made of fabrics and different types of wood, most commonly bamboo. The masks are rich in symbolism. Every colour, every feature of a mask, every constituent element of a mask has a meaning, pointing to the character of a deity, demon or ancestor Outside of the rite though a mask is not treated with a special respect - it is stuffed in a box, hung on a wall or put in a pantry. But when worn during a religious ceremony the mask turns into the face of a deity, and the person wearing the mask, at least on a sacred level, is perceived as a deity itself. "The person wearing the mask becomes sacred," explained participants in religious ceremonies with masks in Guizhou province (Zhuan, Guo, Zhang 2020, 49). 

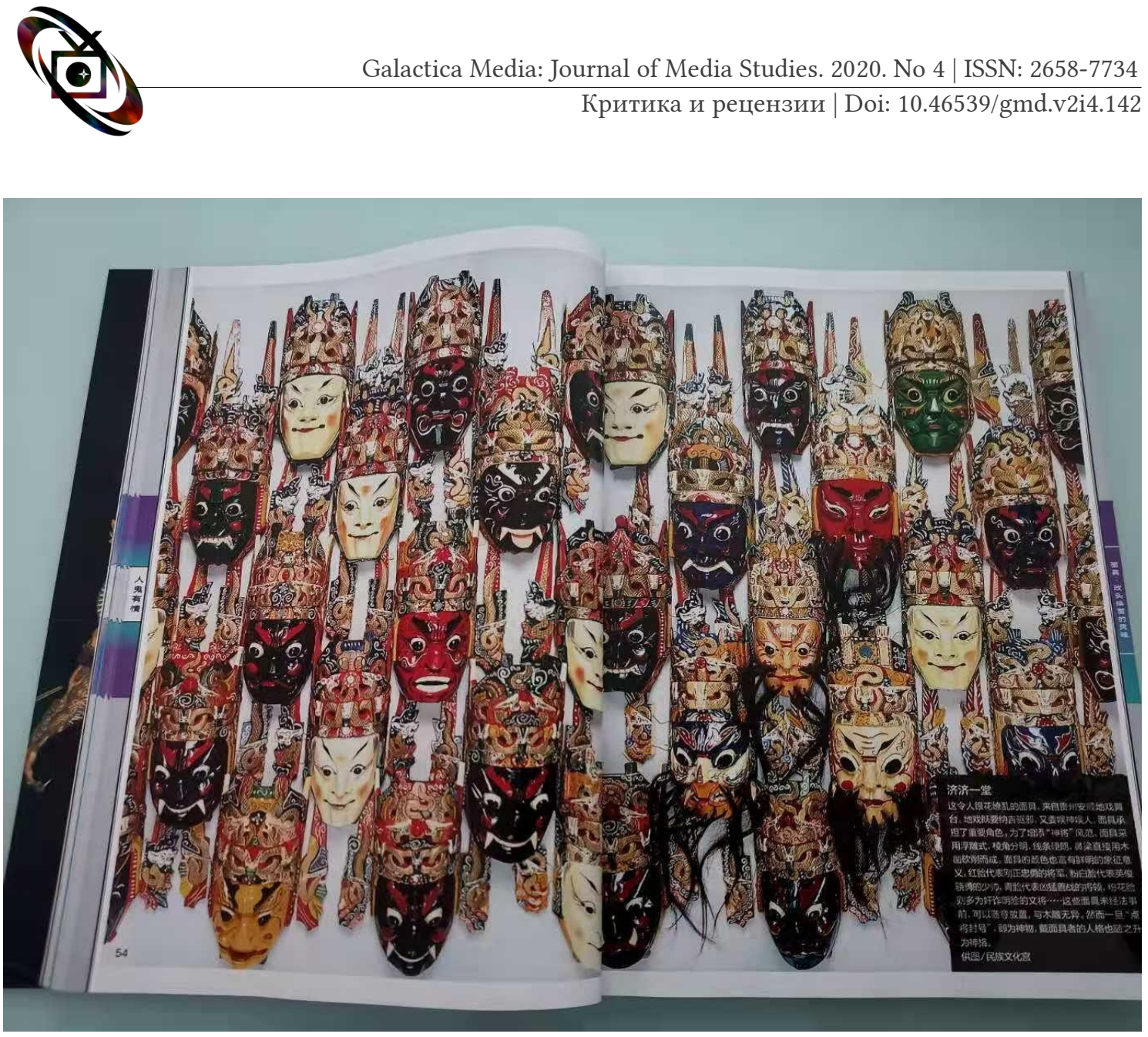

Picture 5. "Cultural Heritage of China". The special issue of 2020. The article about ritual masks

In Linshan county, Guangxi province, masks are worn during sacrifices to ancestral spirits traditionally made by women. In doing so, a witch dance is performed. The ritual is sometimes called "the game of ghosts". The essence of the ritual is that the masked dancer embodies the worshiped spirit, which gives her the strength and power to carry out the actions desired by the community - for example, to leave the village, taking away the disease with her. The dancers themselves explain that they "absorb the power of deity" during the masked sacrifice ceremony.

In the neighbouring province of Guizhou, in the city of Anshun, mask dancing is a male activity. Here, participants dress up in dressing gowns and take weapons in their hands. Their painted masks represent the warrior ancestors, and the whole dance depicts a battle with demons that the dancers are driving out of the borders of the human world.

In Yunnan province, on the border with Myanmar, sacrifice to the spirits with masks is practiced by the Wa people, Chinese 'bounty hunters' (until recently, a human skull or severed head was an essential 
attribute of the Wa rituals). Before wearing the mask, participants are advised to think about the deity they will have to personify, then supernatural powers will come down on the wearer of the mask.

Interviewed by Chinese ethnographers, believers describe their experiences during ceremonies in a fairly straightforward way: "When I put on a heavy mask, I do not know who I am anymore" (ibid., p. 46), "At that moment I became a spirit", "The human and divine are merging and transforming" (ibid., p. 54) One of the interviewees even expressed his reflections in this figurative form: "Gods and spirits are in darkness, you cannot see them, you cannot touch them, but they are kept in the hearts of our ancestors and exist in colourful masks. To understand God, you have to wear a mask" (ibid., page 35).

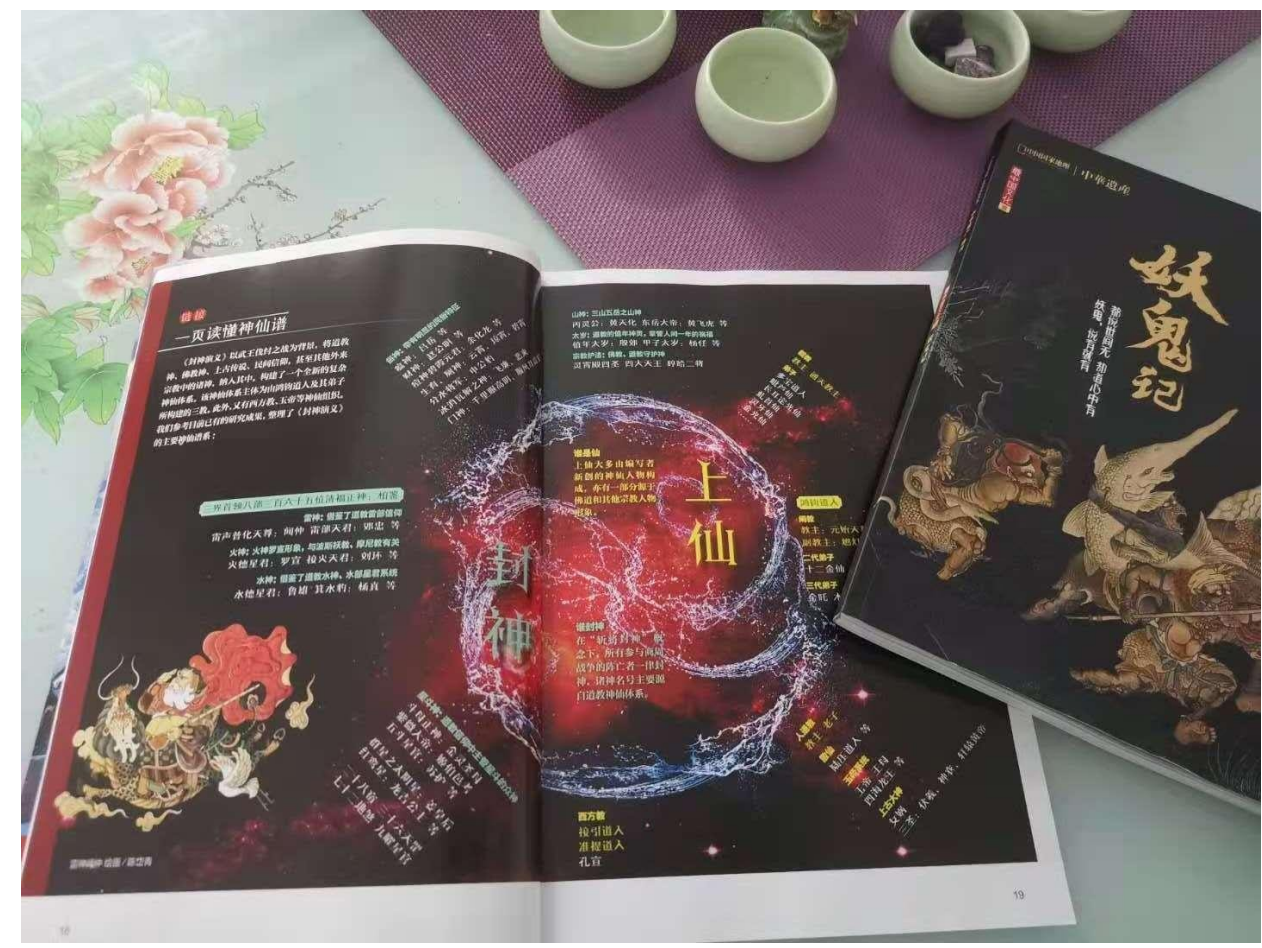

Picture 6. "Cultural Heritage of China”. Issue No4 of 2020. An article about Chinese minor deities

Thus the data offered by the journalists of this issue do have scientific value, for they show that in the southern regions of modern industrial China still exist religious practices of evocation and impersonation of spirits and demons, allowing the believers to merge on an emotional and ecstatic level with the objects of their veneration and to protect themselves from the disasters often caused by the same spirits and demons. 


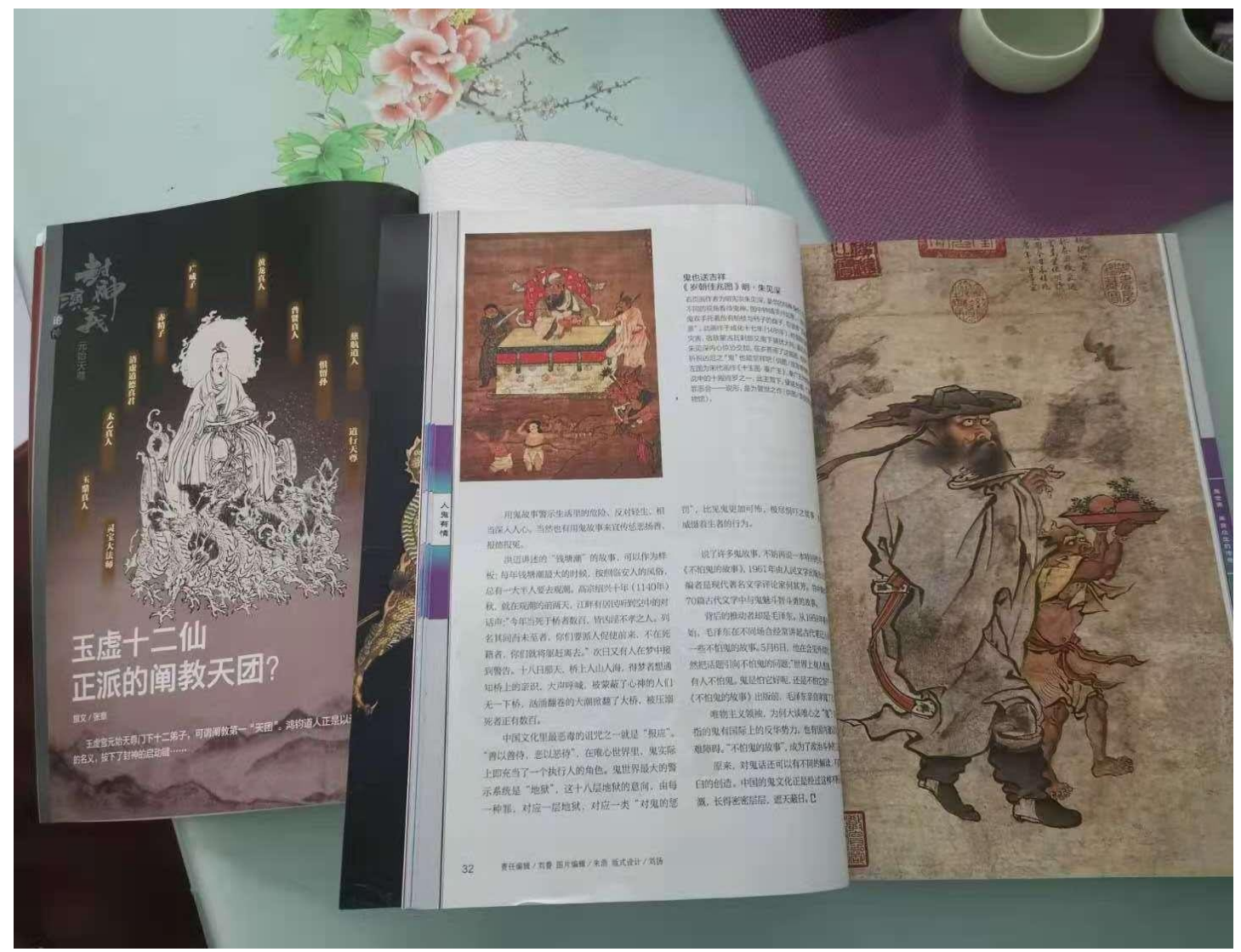

Picture 7. "Cultural Heritage of China". The special issue of 2020. The leading article "The World of the Demons"

To sum it up, the "Cultural Heritage" magazine demonstrates a set of features very typical for Chinese humanitarian studies in general. It is less interested in research than in educating the public and transmitting the cultural tradition, it disregards the necessity to prove, and prefers statements bordering on indoctrination. It pays special attention to the aesthetic side of the subject matters, which can be seen both in the beauty of the illustrations and in the picturesque, fiction-like wording of the articles. The patriotic pride characteristic for this periodical leads it to diminish other national traditions and to overlook their innovative potential, ascribing all the inventions to the Chinese. Yet this very infatuation with all things Chinese becomes the magazine's strong point when it comes to exploring local cultures of China. 


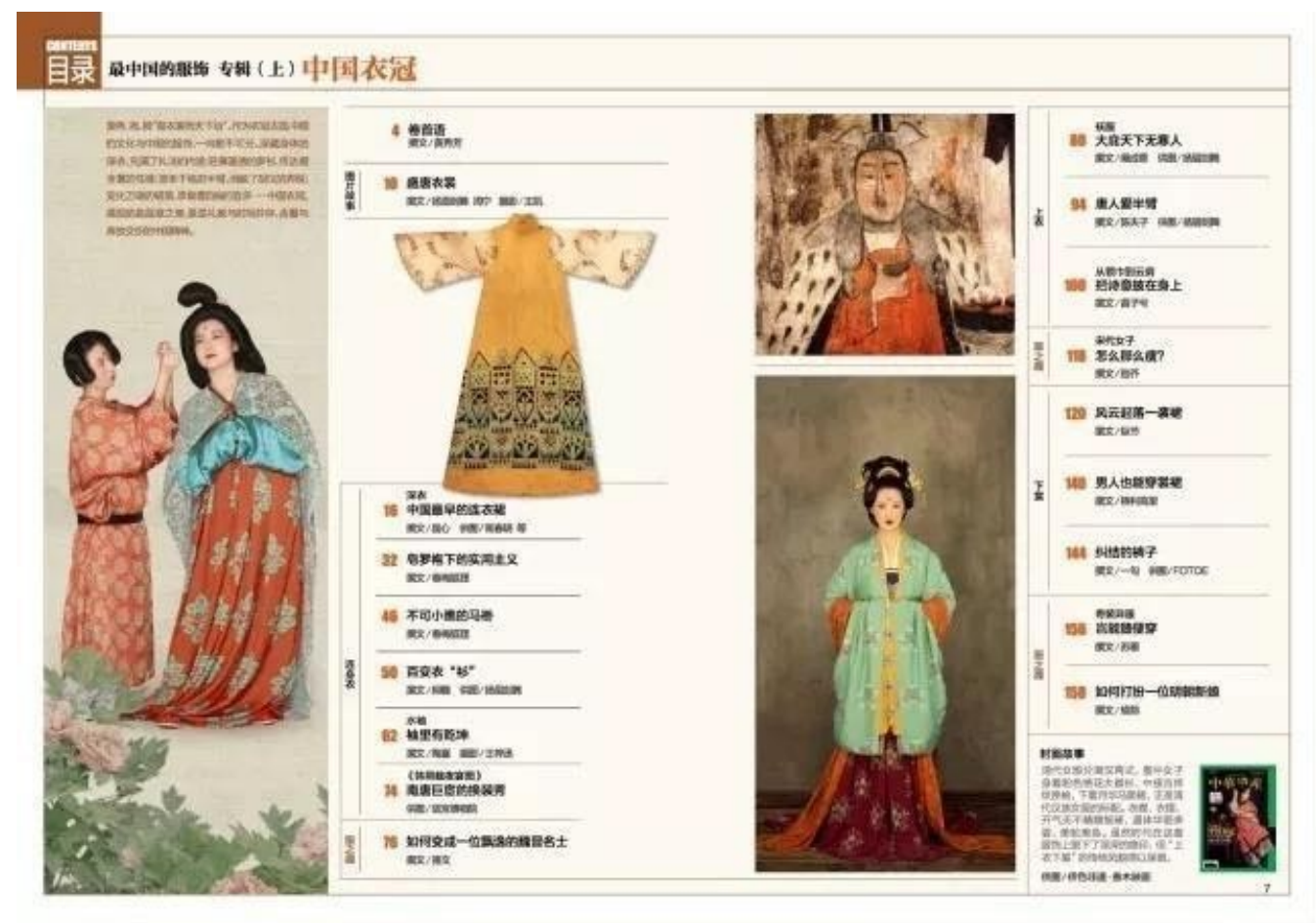

Picture 8. "Cultural Heritage of China”. The issue of 2017 No 12. The index page

\section{References}

国家地理大王一名 ( 2019,11 月 24 日)。星球地理探索。如何评价《中华遗产》智 慧。检索在 https://www.zhihu.com/question/309381 007/answer/583006182 (The King of National Geography (2019, November 29). The exploration of "Planet Geography". How to appreciate "Cultural Heritage of China"? Wisdom. Retrieved from https://www.zhihu.com/question/309381 007/answer/ 583006182 )

刘勃（2017）一代考红：长安城的考试季。中华遗产。(6), 15-30. (Liu, B. (2017). The examination fever of the times: the season of state examinations in Changan city. Cultural Heritage of China. (6), 8-13.)

小溪 ( 2016 ) 百鬼夜行与中国的裙带关系。中华遗产。百鬼夜行 : 从中国出口的 妖怪们 (8), 5-11. (Xiao, X. (2016). The interrelation between The Night Parade of Demons and China. Cultural Heritage of China. Ghosts of the Night: Monsters exported from China, (8), 5-11.)

是谁半遮桃花面 (2017)中华遗产。中国衣冠 (11), 41-42. (Who is there half-covering her peach-blossom face (2017). Cultural Heritage of China. Chinese Robs and Headdresses, (11), 41-42.)

裙间环佩响叮当 (2017)中华遗产。最中国的服饰：中国衣冠 (12), 15-30. (Jingling rings on the skirt (2017). Cultural Heritage of China. Most Chinese of all Clothing: Chinese Robs and Headdresses. (12), 15-30.) 
撰, 郭 \&张 (2020) 撰文，郭净，张晶。面具。改头换面的灵魂。中华遗产。妖鬼记, 34-55. (Zhuang, W., Guo, J., \& Zhang, J. (2020). Masks. The soul of a makeover. Cultural Heritage of China. The Book of Ghosts and Demons, 34-55.)

盛文强 (2020) 盛文强。怪客僵尸不了情。中华遗产。妖鬼记, 87-97. ( Sheng, W. (2020). Zombie, the merciless visitor. Cultural Heritage of China. The Book of Ghosts and Demons, 87-97)

Glahn, R. von (2004). The Sinister Way: The Divine and the Demonic in Chinese Religious Culture. USA: University of California Press.

Katz, P. (1987). Demon or Deities? The Wangye of Taiwan. Asian Folklore Studies, (46), $197-215$.

\section{Список литературы}

国家地理大王一名 ( 2019,11月 24 日)。星球地理探索。如何评价《中华遗产》智 慧。检索在 https://www.zhihu.com/question/309381 007/answer/583006182 (The King of National Geography (2019, November 29). The exploration of "Planet Geography". How to appreciate "Cultural Heritage of China"? Wisdom. Retrieved from https://www.zhihu.com/question/309381007/answer/ 583006182 )

刘勃（2017）一代考红：长安城的考试季。中华遗产。 (6), 15-30. (Liu, B. (2017). The examination fever of the times: the season of state examinations in Changan city. Cultural Heritage of China. (6), 8-13.)

小溪（2016）百鬼夜行与中国的裙带关系。中华遗产。百鬼夜行：从中国出口的 妖怪们 (8), 5-11. (Xiao, X. (2016). The interrelation between The Night Parade of Demons and China. Cultural Heritage of China. Ghosts of the Night: Monsters exported from China, (8), 5-11.)

是谁半遮桃花面 (2017)中华遗产。中国衣冠 (11), 41-42. (Who is there half-covering her peach-blossom face (2017). Cultural Heritage of China. Chinese Robs and Headdresses, (11), 41-42.)

裙间环佩响叮当 (2017)中华遗产。最中国的服饰：中国衣冠 (12), 15-30. (Jingling rings on the skirt (2017). Cultural Heritage of China. Most Chinese of all Clothing: Chinese Robs and Headdresses. (12), 15-30.)

撰, 郭 \&张 (2020) 撰文，郭净，张晶。面具。改头换面的灵魂。中华遗产。妖鬼记, 34-55. (Zhuang, W., Guo, J., \& Zhang, J. (2020). Masks. The soul of a makeover. Cultural Heritage of China. The Book of Ghosts and Demons, 34-55.)

盛文强 (2020) 盛文强。怪客僵尸不了情。中华遗产。妖鬼记, 87-97. ( Sheng, W. (2020). Zombie, the merciless visitor. Cultural Heritage of China. The Book of Ghosts and Demons, 87-97)

Glahn, R. von (2004). The Sinister Way: The Divine and the Demonic in Chinese Religious Culture. USA: University of California Press.

Katz, P. (1987). Demon or Deities? The Wangye of Taiwan. Asian Folklore Studies, (46), $197-215$. 